ANADOLU, J. of AARI

ISSN: 1300-0225 (Print)

E-ISSN: 2667-6087 (Online)

2019, 29 (2): 121-139

DOI: $10.18615 /$ anadolu.660303

\title{
Sulu ve Kuru Koşullarda Yetiştirilen Makarnalık Buğday (Triticum durum L.) Genotiplerinde Bazı Kalite Özelliklerinin Miksograf Cihazı ile Değerlendirilmesi
}

\author{
Berat DEMIR $^{1} *$ (D) Mehmet ŞAHIN ${ }^{2}$ (D) Aysun GöÇMEN AKÇACIK ${ }^{3}$ (D) \\ Seydi AYDOĞAN ${ }^{4}$ (D) Sümeyra HAMZAOĞLU ${ }^{5}$ (D) Çiğdem MECITOĞLU GÜÇBíLMEZ ${ }^{6}$

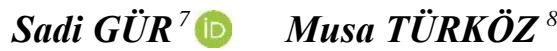

1,2,3,4,5,6,7,8 Bahri Dă̆gdaş Uluslararası Tarımsal Araştırma Enstitüisü, Karatay-Konya/TURKEY

${ }^{1}$ https://orcid.org/0000-0001-6102-2527
${ }^{3}$ https://orcid.org/0000-0002-8209-0796
${ }^{5}$ https://orcid.org/0000-0002-0572-3801
${ }^{7}$ https://orcid.org/0000-0002-1857-8359

*Corresponding author (Sorumlu yazar): berat.demir @ tarimorman.gov.tr

Received (Gelis tarihi): 11.03.2019Ａccepted (Kabul tarihi): 30.07.2019
${ }^{2}$ https://orcid.org/0000-0003-2446-5227
${ }^{4}$ https://orcid.org/0000-0003-0472-1211
${ }^{6}$ https://orcid.org/0000-0003-0670-4546
${ }^{8}$ https://orcid.org/0000-0002-9580-1884

\begin{abstract}
ÖZ: Bu çalışmada bazı makarnalık buğday (Triticum durum L.) çeşitleri ile ileri çıkmış hatlar bazı kalite özellikleri ve miksograf parametreleri yönünden karşılaştırılmış ve özellikler arası iliş̧iler belirlenmiştir. Araştırmada kullanılan materyal Bahri Dağdaş Uluslararası Tarımsal Araştırma Enstitüsü' nde 2016-2017 yetiştirme döneminde kuru ve sulu koşullarda yetiştirilmiştir. Makarnalık buğday örneklerine ait bazı fiziksel, kimyasal ve reolojik özelliklerin yanı sıra bazı miksograf parametreleri (pik zamanı (PT), pik yüksekliği (PV), să̆ pik ĕ̆imi (RPS), son pik genişliği (CT), pik alanı (TNT), toplam alan (TTINT) ve miksograf skala değeri (MS) incelenmiştir. Makarnalı buğday örnekleri gluten kuvvetinin önemli bir göstergesi olan miksograf skala değeri açısından değerlendirildiğinde Eminbey (7,5), Meram (6,0) ve Selçuklu (5,25) çeşitleri ortalamanın $(4,38)$ üzerinde bulunmuştur. Miksogram değerlerinden PT ile SDS $(r=+0,862), D D T(r=+0,791), S T B(r=+0,862)$ arasinda pozitif, DS12 ( $r=-0,848)$ arasinda negatif; PV ile SDS $(r=+0,654)$, DDT $(r=+0,425)$, STB $(r=+0,483)$ arasinda pozitif, CT ile $\operatorname{SDS}(r=+0,820), D D T(r=+0,681)$ ve STB $(r=+0,824)$ arasinda pozitif; TINT ile SDS $(r=+0,855)$, DDT $(r=+0,726)$ ve $\operatorname{STB}(r=+0,853)$ arasinda pozitif ve istatistiksel olarak $p<0,01$ düzeyinde önemli korelasyon değerleri elde edilmiştir. Miksograf cihazının kullanımıyla az miktarda örnekle kısa zamanda makarnalık buğday kalitesi hakkında da önemli sonuçlar elde edilmiştir. Ancak, bu konu yapılacak ileri çalışmalarla miksograf cihazının makarnalık buğdayda kullanımına katkı sağlayacaktır.
\end{abstract}

Anahtar kelimeler: Kalite, makarnalık buğday, Triticum durum L., miksograf.

\section{Evaluation of Some Quality Characteristics in Durum Wheat (Triticum durum L.) Genotypes Grown under Rainfed and Irrigated Conditions by Mixograph Device}

\begin{abstract}
In this study some quality characteristics and mixograph parameters of some durum wheat (Triticum durum L.) varieties and advanced lines were investigated and the relationship between them was determined. The material used in the study was grown in rainfed and irrigated conditions in 2016-2017 growing period at Bahri Dağdaş International Agricultural Research Institute. Some physical, chemical and rheological properties of durum wheat samples as well as some mixograph parameters (peak time (PT), peak height (PV), right peak slope (RPS), final peak width (CT), peak area (TINT) area (TTINT) and mixograph scale (MS) were examined. When durum wheat samples were evaluated in terms of MS which is an important indicator of gluten strength, Eminbey (7.5), Meram (6.0) and Selçuklu (5.25) varieties were found above the average (4.38). Positive correlation was obtained between PT and SDS (0.862), DDT ( $r=+0.791), S T B(r=+0.862)$; and negative correlation was obtained between DS12 $(r=-0,848)$. Positive correlation was obtained between PV and SDS $(r=+0.654), D D T$ $(r=+0.425)$ and STB $(r=+0.483)$. Positive correlation was obtained between CT and SDS $(r=+0.820), D D T(r=+0.681)$ and STB $(r=+0.824)$ TINT and SDS $(r=+0.855), D D T(r=+0.726)$ and STB $(r=+0.853)$ and significant at $p<0.01$, statistically. In this study, with the use of a mixer, a small amount of sample was obtained in a short time about the quality of durum wheat. However, this subject will contribute to the use of mixograph device in durum wheat with further studies.
\end{abstract}

Keywords: Quality, durum wheat, Triticum durum L., mixograph. 


\section{GİRIŞ}

Tahıla dayalı beslenmenin yaygın olduğu ülkemizde makarnalık buğday (Triticum durum L.) önemli bir yere sahiptir. Makarnalık buğdaylar özellikle makarna ve bulgur başta olmak üzere az miktarda da olsa ekmek üretimi için sanayide hammadde olarak kullanılmaktadır. Makarnalık buğdayın son ürün olan makarna ve bulgura işlenmesi sebebiyle hammadde ne kadar kaliteli olursa tüketici beğenisi de o derece yüksek olmaktadır. Dolayısıyla üretimde verimin yanında kaliteyi de iyileştirmek amacıyla çalışmalar yapilmalıdır.

Dünyada makarna yapımında esas olarak durum buğdayının kullanılmasının temel nedenlerinden biri; makarnanın pişme kalitesinin oldukça iyi olması ve arzu edilen parlak sarı rengin birçok ülkede tercih sebebi olmasıdır (Edwards ve Dexter, 2009). Kaliteli bir makarnada ilk akla gelen dış görünüş, renk ve pişme kalitesidir. Pişme kalitesini belirleyen en önemli faktör ise protein miktarıdır. (Feillet ve Dexter, 1996). Protein miktarı çevre ve genotipten önemli düzeyde etkilenmektedir (Atl1 1985; Atl1, 1987; Nachit ve ark., 1995; Bushuk, 1998; Sakin ve ark., 2011). Makarnalık buğdayda kalite kriterleri; protein oran1 tercihen \%13-14, sar1 pigmenti 5-7 ppm arasında, camsılığ1 \%50' den fazla, irmik verimi yüksek ve lipoksidaz aktivitesi düşük olarak özetlenebilir (Elgün ve Ertugay, 1995). Durum buğdaylarının ekmekçilik kalitesi ekmeklik buğdaylara göre daha zayıftır. Bunun sebebi de yapılarında bulunan glutenin ekmeklik buğdaylarla kıyaslandığında daha zayıf ve düşük elastikiyette olmasıdır. Su tutma kapasiteleri ise öğütme esnasında zedelenmiş nişasta miktarları fazla olduğu için ekmeklik buğdaylara göre daha yüksektir. Gelişme süreleri ise ekmeklik buğdaylara göre daha düşüktür (Bakhshi ve Bains, 1987; Boyacıoğlu ve D'Appolonia, 1994).

Aydemir ve ark. (2003) tarafından yapılan bir çalışmada 1967-2002 yılları arasında farklı bölgelerdeki 39 makarnalık buğday çeşidine ait verim ve kalite parametreleri değerlendirilmiştir. Üretime uygun yetiştirme teknikleri kullanılarak kaliteli ve standart ürün elde edilmesinin makarna sanayicileri açısından büyük önem taşıdığı belirtilmiştir. Bunların yanında hızlı test yöntemleri ile belirlenen bazı özellikler erken generasyonda daha az miktarda buğday örneğinde daha çabuk sonuçlar alınmasına olanak sağlamaktadır. Miksograf cihazına ait bazı parametreler hem ekmeklik hem de makarnalık buğdaylarda birçok kalite özeliklerine ait güvenilir sonuçlar vermektedir.

Reoloji; miktar olarak un içerisinde bulunmayan, unun hamur yapımına işlenmesi esnasında hamurun davranışlarını belirleyen ve farinograf, miksograf, alveograf, ekstensograf, miksolab vb. cihazlarla tespit edilen özellikler olarak adlandırılmaktadır. Miksograf ise sabitleştirilmiş ve dönen pimler aracilığıyla un ve suyun karıştırılarak hamurun yoğrulmaya karşı direncini ölçmekte ve böylece buğday ve un kalitesi hakkında fikir vermektedir (Dong ve ark., 1992; Khatkar ve ark., 1996). Miksograf cihazının buğdaylarda reolojik özelliklerin belirlendiği diğer cihazlardan ayrılan özelliği; daha az miktarda örnekle daha kısa sürede analizin tamamlanmasıdır (Atl1 ve ark., 1992). Analiz sonucunda elde edilen grafikle protein kalitesi, yoğrulmaya karşı direnç ve hamurun optimum yoğrulma zamanı yorumlanabilmektedir (Bağcı ve Şahin, 1999).

$\mathrm{Bu}$ çalışmanın ana amacını; makarnalık buğday çeşitleri ile ileri çıkmış bazı hatlarda bazı fiziksel ve kimyasal kalite özelliklerinin farinograf ve miksograf parametreleri yönünden karşılaştırılarak, özellikler arası ilişkilerin belirlenmesi oluşturmuştur.

\section{MATERYAL VE METOT}

Deneme Bahri Dağdaş Uluslararası Tarımsal Araştırma Enstitüsü Konya-Merkez lokasyonunda, 2016-2017 yetiştirme döneminde, kuru ve sulu koşullarda olmak üzere iki ayrı çevre şartlarında yetiştirilen 7 adet tescilli çeşit ve 2 adet ileri çıkmış hat olmak üzere toplam 9 adet makarnalık buğdaydan (Ç-1252, Eminbey, Kizıltan, Meram2002, Selçuklu-97, Türköz ve Yelken-2000 çeşitleri ile makarnalık buğday hattı olarak Amber ve KMBVD-3 aday hatları) oluşmuştur.

Sulu ve kuru koşullarda Tesadüf Blokları Denme Deseninde iki tekerrürlü olarak yürütülen 
B. DEMIR, M. SAHIN, A. GÖCMEN AKCACIK, S. AYDOĞAN, S. HAMZAOĞLU, C. MECITOĞLU GÜÇIILMEZ, S. GÜR, M. TÜRKÖZ: SULU VE KURU KOŞULLARDA YETIŞTİRILEN MAKARNALIK BUĞDAY (Triticum durum L.) GENOTIPLERINDE BAZI KALİTE ÖZELLIKLERİNIN MIKSOGRAF CİHAZI İLE DEĞERLENDİRILMESI

denemelerden elde edilen buğday örnekleri laboratuvarda analiz edilmiştir.

Buğday örnekleri AACC (26-95)'ye göre (\% 16 rutubet olacak șekilde) tavlanmış, AACC (26-50)' ye göre Brabender Junnior değirmende öğütülerek elde edilen irmiklerde Hunterlab marka Mini Scan XEplus isimli cihazla renk (b) değeri okunmuştur (Anonymous, 2000). Bin tane ağırlığ 1 (g) AACC (55-10) metoduna göre (Anonymous, 2000) tayin edilmiştir. Hektolitre ağırlığ $(\mathrm{kg})$ ve SDS (sodyum dodesil sülfat) sedimantasyon (ml) testi Williams ve ark. (1988)' e göre, Protein oranı (\%) (NIR) AACC 39-10 metoduna göre (Kjeldhal metodu ile 5,7 faktörü ile kalibre edilmiştir.) (Anonymous, 2000), Farinograf analizleri AACC 54-21' e göre, Miksograf analizi National Mfg.Co. Lincoln. NE miksograf cihazı kullanılarak yapılmıştır(AACC 54-40). Mixsmart yazılımı ile sonuçlar bilgisayar ortamından alınmıştır (Walker ve ark., 1997).

Laboratuvar analizlerinden elde edilen veriler istatistiksel olarak birleştirerek sulu-kuru koşulların birleştirilmiş analiz sonuçları şeklinde Jump 11 programında (Anonymous, 2014) iki tekerrürlü olarak Tesadüf Blokları Deneme Deseni dizaynında varyans analizine tabi tutulmuş olup, ortalamaların karşılaştırılması AÖF (asgari önemli fark) Student's Test yöntemine göre yapılarak, özellikler arası korelasyonlar hesaplanmıştır (Steel ve Torrie, 1980; Yurtsever, 1984).

\section{BULGULAR VE TARTISSMA}

Denemede kullanılan makarnalık (Ç-1252, Eminbey, Kızıltan, Meram-2002, Selçuklu-97, Türköz ve Yelken-2000) çeşitler ile makarnalık buğday hattı olarak Amber ve KMBVD-3 aday hatlarına ait bazı fiziksel ve kimyasal analiz sonuçları Çizelge 1' de verilmiştir.

\section{Fiziksel ve Kimyasal Analiz Sonuçları}

Makarnalık buğdayların bazı fiziksel ve kimyasal özelliklerine ait varyans analiz sonuçlan Çizelge 1'de belirtilmiştir. Makarnalık buğday genotiplerine ait bin tane, hektolitre, protein, sedimantasyon ve renk değerleri arasındaki fark istatistiki olarak $\mathrm{p}<0,01$ düzeyinde önemli bulunmuştur. Çevre şartlarına ait bin tane ve sedimantasyon değerleri arasındaki fark $(p<0,01)$ ile hektolitre ve protein miktarları arasındaki fark $(\mathrm{p}<0,05)$ istatistiki olarak önemli bulunurken renk değerleri arasındaki fark önemsiz bulunmuştur. Genotip X Çevre interaksiyonuna ait renk değeri arasındaki fark $(\mathrm{p}<0,01)$ istatistiki olarak önemli bulunurken, bin tane, hektolitre, protein ve SDS sedimantasyon değeri önemsiz bulunmuştur.

Bin tane: Sonuçlar bin tane ağırlı̆ğ yönünden ele alındığında; deneme ortalamasının 47,42 g olduğu Ç-1252 ve Yelken çeşitlerinin deneme ortalamasının üzerinde olduğu belirlenmiştir (Çizelge 1). En yüksek bin tane ağırlığı ise Türköz $(54,29 \mathrm{~g})$ çeşidinden elde edilmiştir. Kendal ve ark. (2012), yaptıkları çalışmada Adıyaman lokasyonundaki bazı makarnalık buğday çeşitlerinde bin tane ağırlıklarını ortalama 37,5 g olarak belirtmişlerdir. Turan (2008), yapmış olduğu bir araştırmada makarnalık buğdaylarda ortalama bin tane ağırlığını 46,9 g olarak bildirmiştir. Bin tane ağırlığında farklılıklar tanelerin genetik yapısıyla alakalı olup, çevre koşullarından en az etkilenen önemli verim ögelerinden biridir (Blue ve ark., 1990).

Hektolitre: Denemede hektolitre ağırlığı 75,56$79,44 \mathrm{~kg}$ aralığında değişmiştir (Çizelge 1). En yüksek hektolitre ağırlığ 1 Amber $(79,44 \mathrm{~kg})$ ve en düşük hektolitre ağırlığı ise Kızıltan $(75,56 \mathrm{~kg})$ çeşidinden elde edilmiştir. Hektolitre ağırlığ 1 ; genotip, iklim şartları ve farklı yetiştirme tekniği uygulamalarına bağlı olarak değişebilmektedir. Hektolitre ağırlığının yüksek olduğu çeşitlerde tanelerin protein oranı, sertliği ve un verimi yüksek olabileceği bildirilmiştir (Yürür, 1994). Yapılan bir çalışmada Diyarbakır ve Adıyaman lokasyonlarında ekilen makarnalık buğdayların ortalama hektolitre ağırlıkları sırasıyla $78,3 \mathrm{~kg}$ ve $77,2 \mathrm{~kg}$ olarak belirlenmiştir (Kendal ve ark., 2012).

Protein: Makarnalık buğdaylara ait protein miktarı ortalama \% 12,57 olarak bulunmuştur (Çizelge 1). Kılıç ve ark. (2012) bazı makarnalık buğday hatları ve çeşitlerini verim ve kalite özellikleri yönünden değerlendirmişler ve protein miktarlarının \%13,1211,72 arasında değiştiğini belirtmişlerdir. Protein miktarının yüksek olması (\%13'ten fazla) istenmekte ve protein kalitesinin pişme kalitesini doğrudan etkileyen faktör olduğu belirtilmektedir (Troccoli ve ark., 2000; D’Ovidio ve Masci, 2004). 


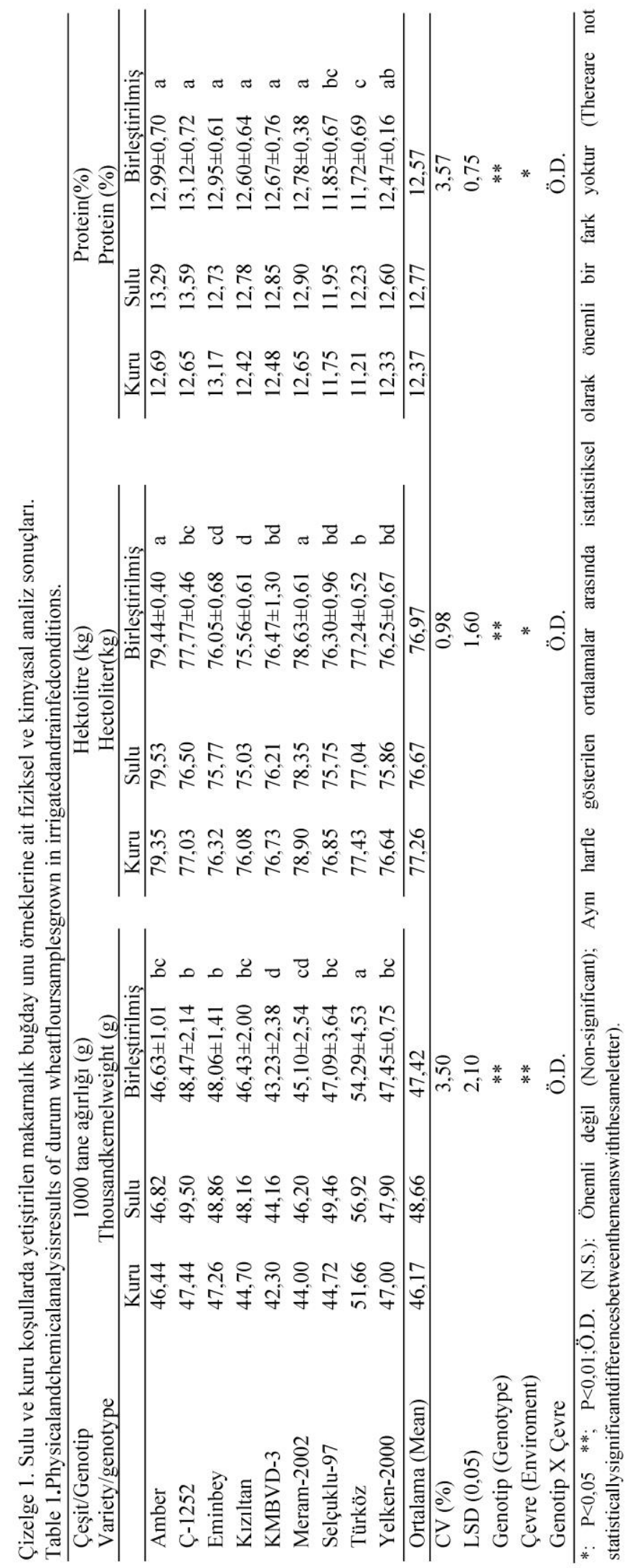


B. DEMIR, M SAHIN, A. GÖCMEN AKCACIK, S. AYDOĞAN, S. HAMZAOĞLU, C. MECİTOĞLU GÜCBİLMEZ, S. GÜR, M. TÜRKÖZ: SULU VE KURU KOSULLARDA YETISTIRILEN MAKARNALIK BUĞDAY (Triticum durum L.) GENOTIPLERINDE BAZI KALİTE ÖZELLIKLERİNIN MIKSOGRAF CIHAZI İLE DEĞERLENDIRILMESI

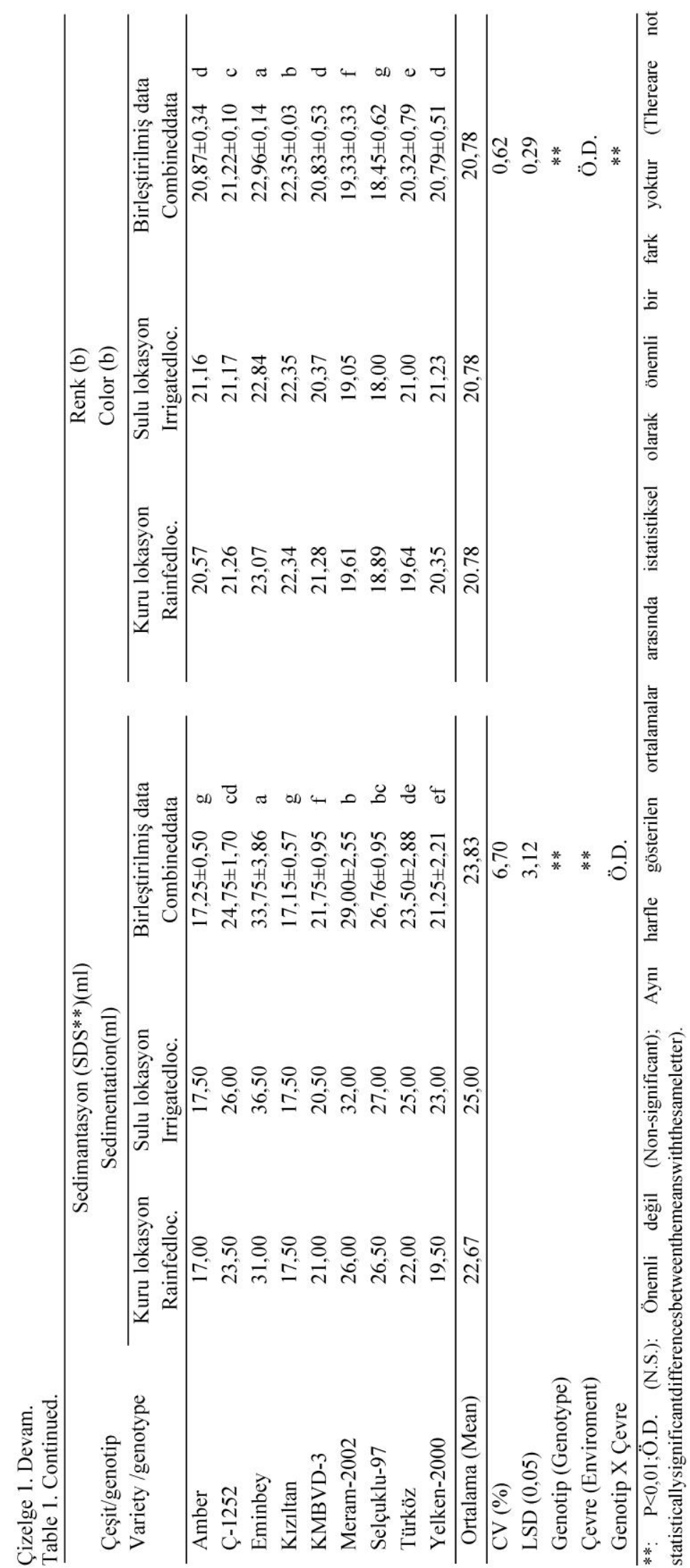


Sedimantasyon: Çizelge 1'e göre denemede elde edilen ortalama sedimantasyon (SDS) değeri 23,83 ml olarak belirlenmiştir. En yüksek ve en düşük SDS sedimantasyon değerleri ise sirasiyla Eminbey $(33,75 \mathrm{ml})$ ve Kiz1tan $(17,15 \mathrm{ml})$ çeşitlerinden elde edilmiştir. Kovacs ve ark. (1995), makarnalık buğdaylarda SDS sedimantasyon değerini ortalama 26-46 $\mathrm{ml}$ aralığında bulmuşlardır. Sedimantasyon değeri, buğdaylarda protein kalitesi hakkında bilgi veren önemli bir kalite kriteridir (K1lı̧ ve ark., 2012).

Renk: Renk (b) değerleri incelendiğinde ortalama olarak 18,45-22,96 değerleri arasında olduğu tespit edilmiştir (Çizelge 1). En yüksek b değeri Eminbey $(22,96)$ en düşük $b$ değeri ise Selçuklu-97 $(18,45)$ çeşidinden elde edilmiştir. Renk değerleri içerisinde $b$ değeri (sarılık değeri) makarnalık buğdaylar için önemli bir kalite kriteridir. Durum buğdayından elde edilen makarnalardaki parlak sarı renk; tohumda doğal olarak bulunan karotenoid pigmentler, öğütme ve depolama sonrasındaki lipoksigenaz ve diğer bazı enzimler ile makarnanın işlenme koşulları gibi birçok faktörden etkilenmektedir (Borrelli ve ark., 2000). Yapılan bir araştırmada farklı yöntemlerle sarı renk pigment içeriği incelenmiş ve 6 durum buğdayında b değerlerinin 21,1-25,8 arasında değiştiği bildirilmiştir (Coşkun ve ark., 2010). Bir başka çalışmada ise İç Anadolu Bölgesi' ne ait 3 farklı lokasyonda (Altınova, Haymana, Ulaş) yetiştirilen makarnalık buğday genotiplerinde iki farklı renk tayin cihazıyla renk ölçümleri yapılmış ve ortalama b değeri 23,78-23,45 olarak belirlenmiştir (Kaplan Evlice ve Özkaya, 2011) .

Türköz çeşidi hem sulu hem de kuru koşullarda bin tane yönünden en iyi performansı sergilemiştir. Her iki koşulda da elde edilen bin tane değeri ortalamas1 47,42 g olarak belirlenmekle birlikte bin tane ağırlığının 40 gramın üstünde olması makarnalık buğdaylarda istenen bir özelliktir (Dalçam, 1993). Amber çeşidi de hektolitre ağırlığ yönünden her iki koşulda da en yüksek değere sahip olmuştur. Protein oranları karşılaştırıldığında kuru koşullarda Eminbey çeşidi, sulu koşullarda da Ç-1252 en yüksek değeri elde etmiştir. KMBVD-3 hariç tüm çeşitlere ait SDS sedimantasyon değerinde sulu koşullarda $(25 \mathrm{ml})$, kuru koşullardan $(22,67 \mathrm{ml})$ yüksek sonuçlar elde edilmiştir. Renk değeri (b) ise her iki koşulda da Eminbey değerinde en yüksek çıkmıştır (Çizelge $1)$.

\section{Farinograf Analizi Sonuçları}

Makarnalık buğday genotiplerine ait DDT (hamur gelişme süresi), WAC (su absorbsiyon kapasitesi), STB (stabilite) ve DS12 (12. dakikadaki yumuşama derecesi) parametreleri arasındaki fark istatistiksel olarak önemli bulunmuştur $(p<0,01)$. Çevre şartlarına ait STB değerleri arasındaki fark istatistiki olarak önemli $(\mathrm{p}<0,01)$ bulunurken DDT, WAC ve DS12 değerleri arasındaki fark önemsiz bulunmuştur. Genotip X Çevre interaksiyonu açısından değerlendirildiğinde WAC ve DS12 değerleri arasındaki fark istatistiki olarak önemli $(\mathrm{p}<0,05)$ bulunurken DDT ve STB değerleri arasındaki fark istatistiki açıdan önemsiz bulunmuştur (Çizelge 2).

Hamur gelişme süresi: Çizelge 2'de değerlendirilen hamur gelişme süresi (DDT) ortalama $2,73 \mathrm{dk}$. olmuş, en uzun ve en kısa hamur gelişme sürelerine sirasiyla Eminbey ve Selçuklu-97 çeşitleri sahip olmuştur. Yapılan bir araştırmada 3 farklı İtalyan durum buğdayına ait DDT değerlerinin $2,8,3,3$ ve $4,0 \mathrm{dk}$. olduğu belirtilmiştir (Edwards ve ark., 1999). Hamur gelişme süresi protein kalitesini tahmin etmede kullanılan önemli bir parametredir (Wang ve ark., 2002). Gelişme süresi çok kısa olan hamurların protein kalitesi düşük olurken çok uzun gelişme süresi de zaman ve enerji kaybı gerekçesiyle istenmeyen bir durumdur (Aydoğan ve ark., 2012b).

Su kaldırma/absorbsiyon kapasitesi: Denemede su kaldırma kapasitesi (WAC) \%61,98 ile 66,02 aralığında değişmiştir. Kaliteli bir buğdayda farinograf su absorbsiyonu değerinin \% 60'1n üzerinde olması istenir (Ercan ve ark., 1988). Bu sonuçlara paralellik gösteren bir başka çalışmada ekmeklik buğday çeşitlerine ait farinograf su absorbsiyonu deneme ortalamas1 \% 61,20 olarak bulunmuştur (Aydoğan ve ark., 2013). 
B. DEMIR, M. SAHIN, A. GÖCMEN AKCACIK, S. AYDOĞAN, S. HAMZAOĞLU, C. MECİTOĞLU GÜCBİLMEZ, S. GÜR, M. TÜRKÖZ: SULU VE KURU KOSSULLARDA YETISTTIRILEN MAKARNALIK BUĞDAY (Triticum durum L.) GENOTIPLERINDE BAZI KALİTE ÖZELLIKLERİNIN MIKSOGRAF CIHAZI İLE DEĞERLENDIRILMESI

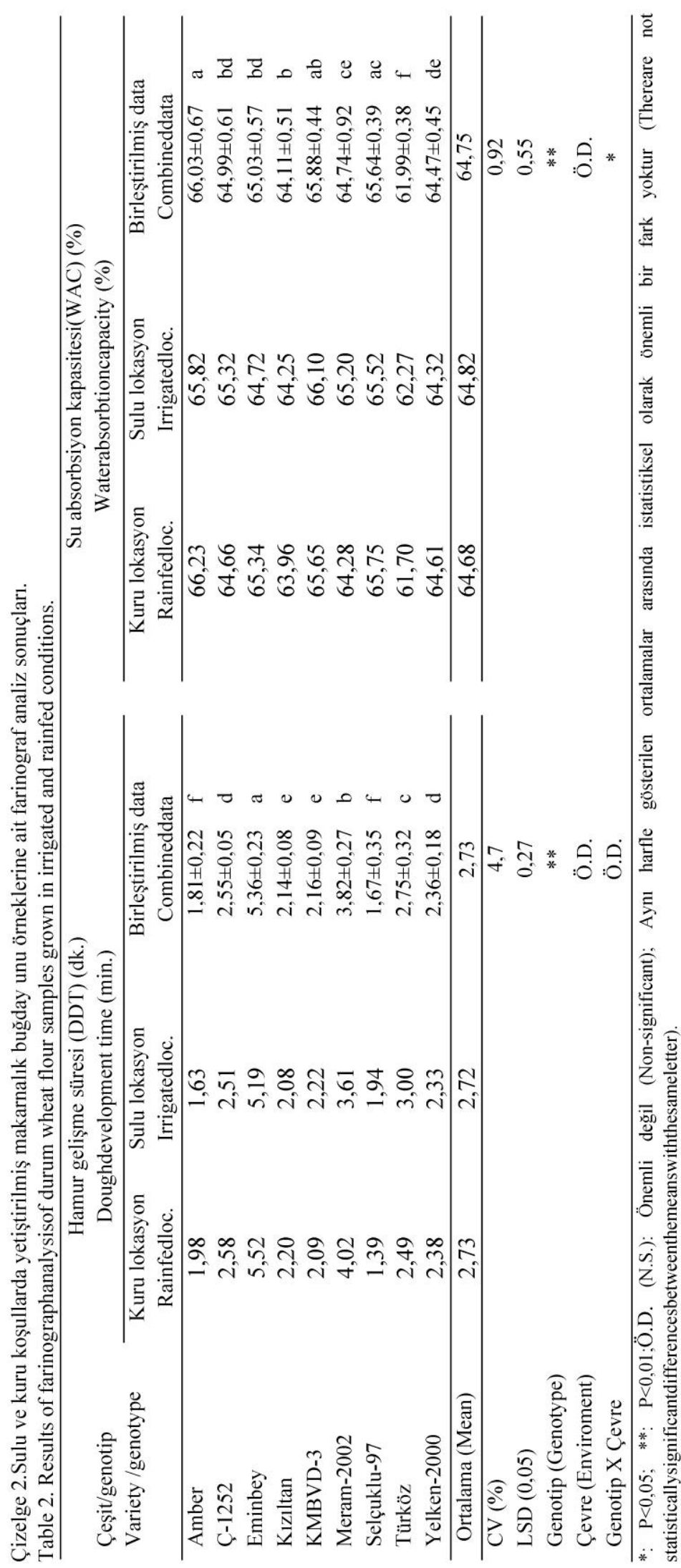




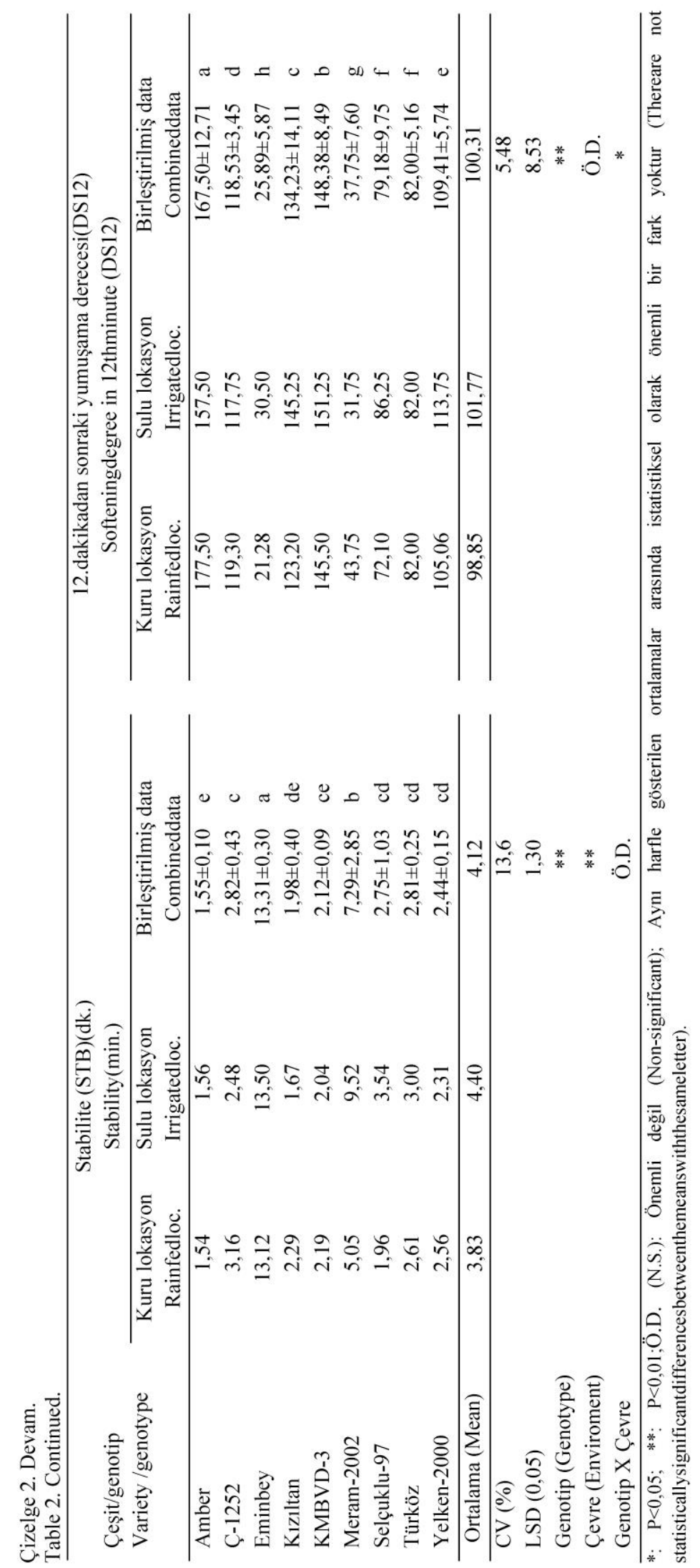


B. DEMIR, M. SAHIN, A. GÖCMEN AKCCACIK, S. AYDOĞAN, S. HAMZAOĞLU, C. MECITOĞLU GÜÇIILMEZ, S. GÜR, M. TÜRKÖZ: SULU VE KURU KOŞULLARDA YETIŞTİRILEN MAKARNALIK BUĞDAY (Triticum durum L.) GENOTIPLERINDE BAZI KALİTE ÖZELLIKLERININ MIKSOGRAF CIHAZI İLE DEĞERLENDİRILMESI

Stabilite: Çizelge 2’ ye göre denemeye ait stabilite (STB) değeri ortalaması $4,12 \mathrm{dk}$. olarak belirlenmiş olup en düşük stabilite Amber $(1,55$ dk.) en yüksek ise Eminbey (13,31 dk.) çeşidinden elde edilmiştir. Stabilite süresinin uzun olması hamurun işlenmeye elverişliliğinin ve elastikiyetinin fazla olduğunu göstermektedir (Özkaya ve Kahveci, 1990; Altan, 1996). Boyacıoğlu ve D'Appolonia (1994) yaptıkları çalışmada, 9 farklı makarnalık buğday ununda ortalama su absorbsiyonunu \%68, stabilite değerini ise $3,5 \mathrm{dk}$. olarak belirtmişlerdir.

Onikinci dakikadaki yumuşama derecesi: Makarnalık buğday unlarına ait 12. dakikadaki yumuşama derecesi (DS12) denemede ortalama 100,31 FU olarak belirlenmiş, yumuşama derecesi en yüksek Amber (167,5 FU) en düşük değer ise Eminbey (25,89 FU) çeşidinden elde edilmiştir (Çizelge 2). İşlenmeye karşı toleransı az olan ve fermantasyon süresi kisa olan buğdaylarda yumuşama derecesi yüksek olmaktadır (Özkaya ve Kahveci, 1990; Altan, 1996).

Çizelge 2' de sulu ve kuru koşullarda yetiştirilen makarna örneklerine ait reolojik analiz sonuçları belirtilmiştir. Eminbey çeşidi hamur gelişme süresi (DDT) ve stabilite (STB) değerleri yönünden her iki koşulda da en yüksek değerlere sahip olmuştur. Su absorbsiyon kapasitesi (WAC) değeri en yüksek sulu koşullarda Amber, kuru koşullarda ise KMBVD-3 genotipinden elde edilmiştir.

\section{Miksograf Analizi Sonuçları}

Makarnalık buğday genotiplerine ait gelişme süresi (PT), pik yüksekliği (PV), sağ pik eğimi (RPS), pik genişliği (CT), zarf alanı (TINT), toplam alan (TTINT) ve miksograf skala parametreleri arasındaki fark istatistiki olarak önemli bulunmuştur $(p<0,01)$. Çevre şartlarına ait CT değerleri arasındaki fark istatistiki olarak $p<0,01$ düzeyinde önemli bulunurken diğer tüm parametreler arasındaki fark önemsiz bulunmuştur. GenotipXÇevre interaksiyonuna ait tüm miksograf parametreleri değerleri arasındaki fark istatistiki yönden önemsiz bulunmuştur (Çizelge 3 ).

Gelişme süresi (Pik zamanı): Çizelge 3'te belirtilen miksograf gelişme süresi 1,54 dk. ile 3,77 dk. arasında değişmiştir. Gelişme süresi (PT) en uzun olan makarnalık buğday çeşidi Eminbey $(3,77$ dk.) olmuștur. Karababa ve Ercan (1995), 3 farklı makarnalık buğdayda gelişme süresinin 1,6-1,8 dk. arasında değiştiğini belirlemişlerdir. Babay ve ark. (2015) ise 35 ekmeklik buğdayda bazı kalite parametrelerini incelemişler ve yapılan miksograf analizinde pik zamanının 0,5-3,9 dk. arasında değiştiğini bildirmişlerdir. Durum buğdaylarında protein miktarı ekmeklik buğdaylara göre daha yüksek olmasına rağmen protein kalitesi ve kuvveti düşüktür (Liu ve ark., 1996). PT; hamurun gelişme süresini ifade etmektedir. Yapılan araştırmalarda PT ile miksograf bant genişliğinin hamurun direncini ifade ettiği belirtilmektedir (Pitz 1997; Pudden 1997; Deng ve ark., 2005). Aydoğan ve ark. (2010), protein miktar ve kalitesi yüksek olan unlarda miksograf gelişme süresinin uzun olduğunu ve buna bağlı olarak hamurun yoğurma süresinin de uzadığını belirtmişlerdir. Benzer bir çalışmada bu sonuçlara paralel veriler elde edilmiş, 21 adet ekmeklik buğdaylarda yapılan miksograf analizi değerlendirmelerinde gelişme sürelerinin 1.61-4.66 dk. arasında değiştiği belirlenmiştir (Aydoğan ve ark., 2013).

Pik yüksekliği: Denemede pik yüksekliği (PV) ortalama \% 61,05 olarak belirlenmiştir. En yüksek PV değeri Meram-2002 $(\% 64,90)$ en düşük PV değeri ise Kizıltan $(\% 54,58)$ çeşidinden elde edilmiştir (Çizelge 3). Hamurun yoğurmaya karş1 gösterdiği direncini gösteren pik yüksekliğinin güçlü çeşitlerde yüksek olması beklenmektedir (Abuhammad ve ark., 2012). Sulu şartlarda 18 adet ekmeklik buğday genotipinin ortalama PV değerinin \% 65,1 olduğu belirlenmiştir (Şahin ve ark, 2016). Yapılan bir çalışmada Aydoğan ve ark. (2012a) 5 farklı makarnalık buğday çeşidine ait pik yüksekliğinin iki yıllık ortalama değerinin \%57,2767,84 arasında değiştiğini belirtmişlerdir.

Sağ pik eğimi (Yumuşama derecesi): Çizelge 3 incelendiğinde sağ pik eğimi (RPS) ortalama 13,58 $\% / \mathrm{dk}$ olarak belirlenmiştir. RPS değeri hamurun yumuşama derecesini göstermektedir, glutenin kuvveti ve hamurun yoğrulmaya karşı toleransı hakkında fikir verir. RPS değeri arttıkça gluten mukavemeti azalarak yoğrulmaya karşı direnç düşer, dolayısıyla bu değerin düşük olması arzu edilir (Şahin ve ark., 2016). Yapılan bir çalışmada makarnalık buğdaylara ait miksograf yumuşama değeri \%22,88-39,17 arasında bulunmuştur (Aydoğan ve ark., 2012a). 


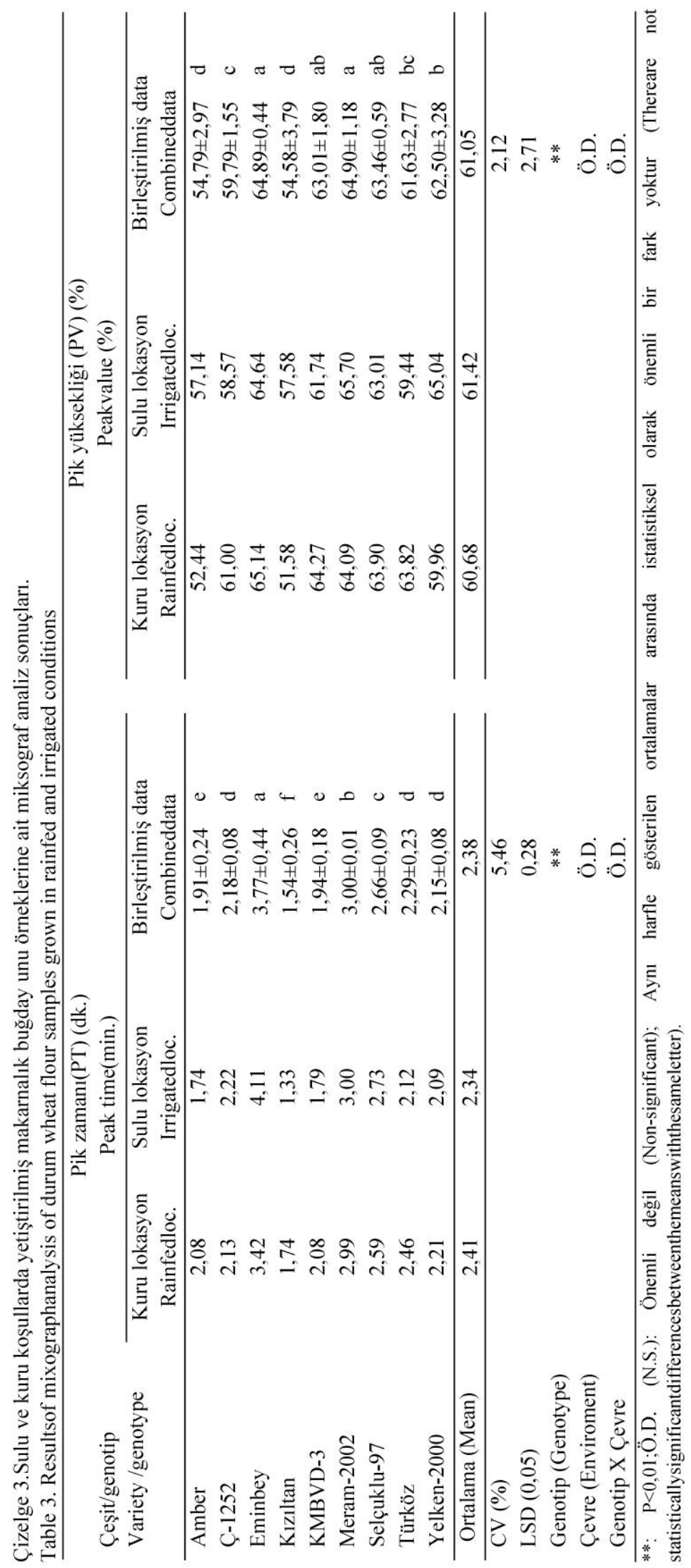


B. DEMIR, M SAHIN, A GÖCMEN AKCACIK, S. AYDOĞAN, S. HAMZAOĞLU, C. MECİTOĞLU GÜCBİLMEZ, S. GÜR, M. TÜRKÖZ: SULU VE KURU KOŞULLARDA YETIŞTIRILEN MAKARNALIK BUĞDAY (Triticum durum L.) GENOTIPLERINDE BAZI KALİTE ÖZELLIKLERININ MIKSOGRAF CİHAZI İLE DEĞERLENDİİLMESİ

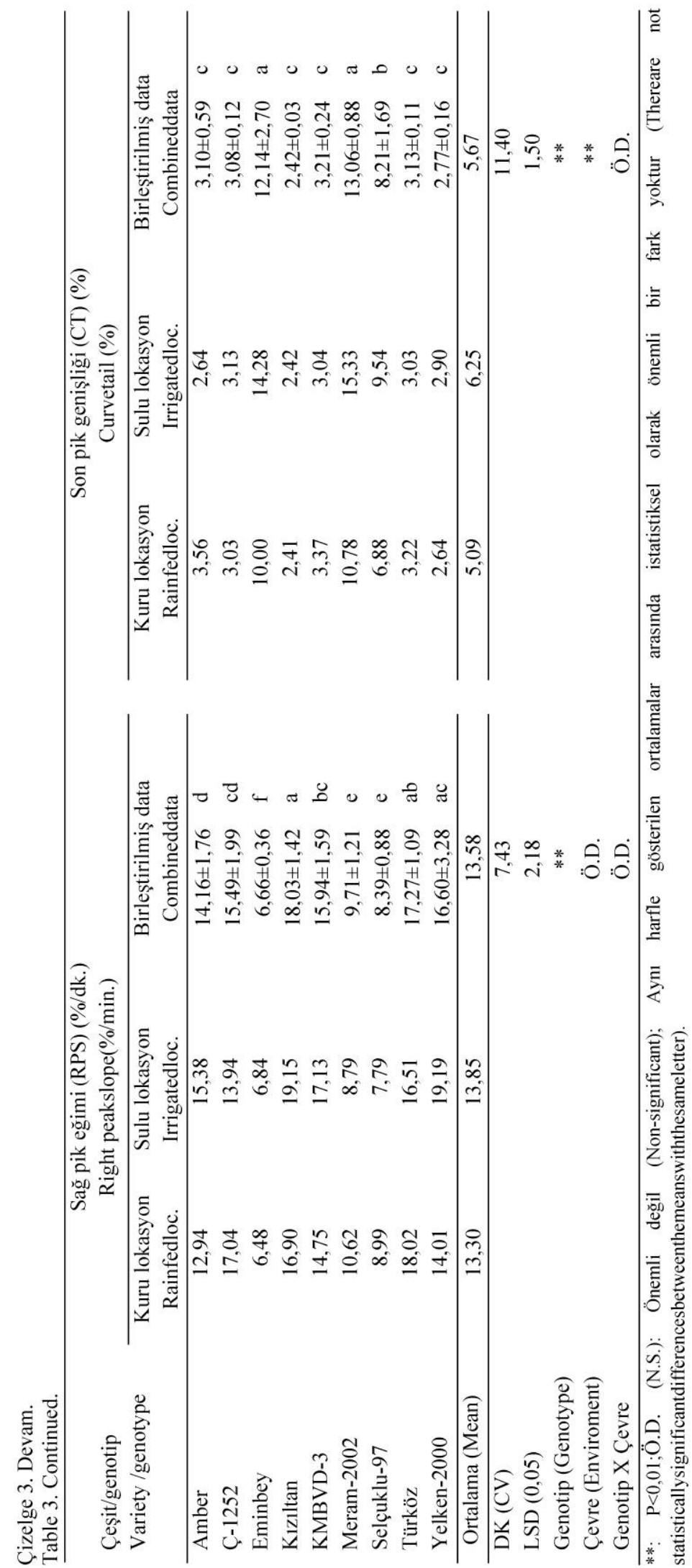




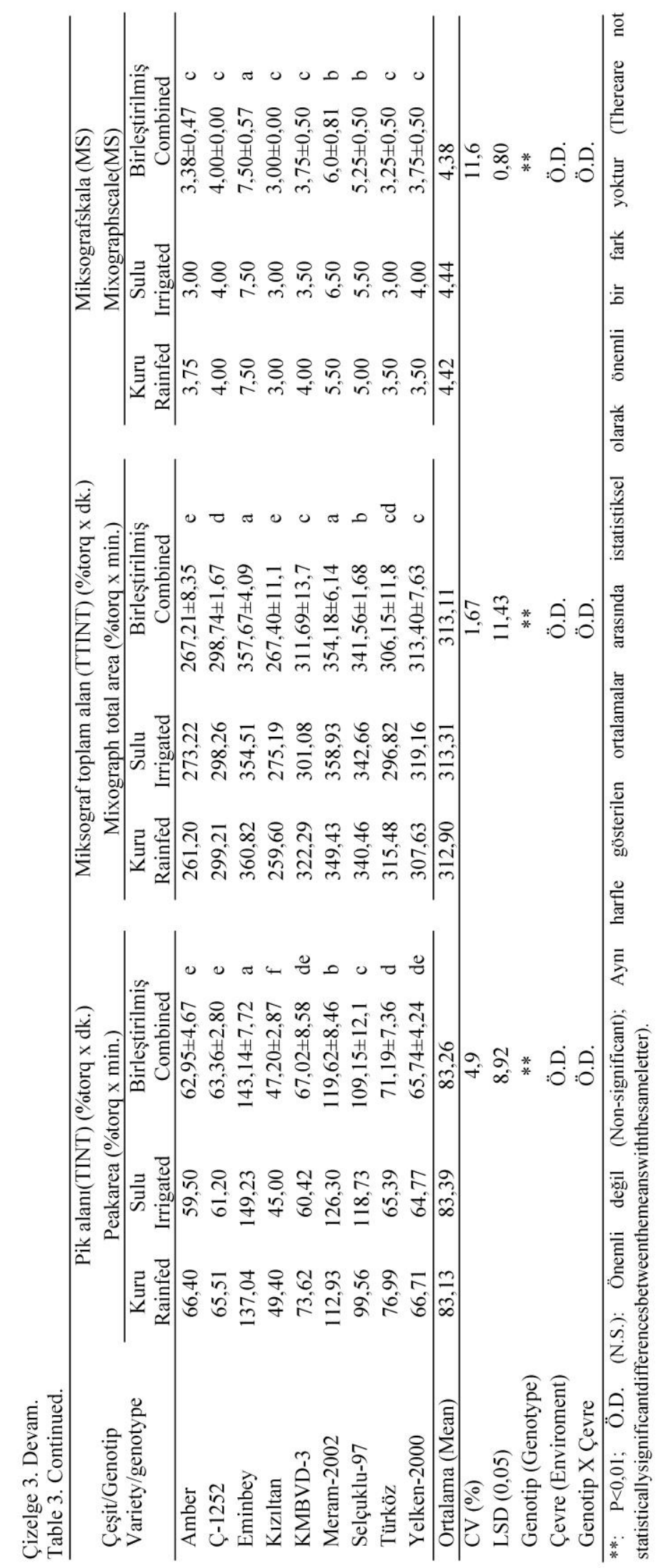


B. DEMIR, M. SAHIN, A. GÖCMEN AKCCACIK, S. AYDOĞAN, S. HAMZAOĞLU, C. MECITOĞLU GÜÇIILMEZ, S. GÜR, M. TÜRKÖZ: SULU VE KURU KOŞULLARDA YETIŞTİRILEN MAKARNALIK BUĞDAY (Triticum durum L.) GENOTIPLERINDE BAZI KALİTE ÖZELLIKLERININN MIKSOGRAF CIHHAZI İLE DEĞERLENDİRILMESI

Pik genişliği: Miksografin bir diğer parametresi olan analiz sonu pik genişliği değeri bu çalışmada ortalama \%5,67 olarak belirlenmiş, Eminbey $(\% 12,14)$ Meram-2002 (\%13,06) ve Selçuklu-97 $(\% 8,21)$ çeşitleri ortalamanın üzerinde değerler vermiştir (Çizelge 3). Son pik genișliği hamurda viskozite kaybının ölçüsü olarak değerlendirilir (Patil ve ark., 2009). Benzer bir çalışmada bazı ekmeklik buğday çeşitleri ve elit hatlarda miksograf ve farinograf analizleri gerçekleştirilmiştir. Analiz sonucunda örneklere ait CT değerinin \%4,89-9,32 aralığında olduğu belirtilmiştir (Sun ve ark., 2015).

Pik (Zarf) alanı: Zarf alanı (TINT) değerleri 47,20143,14 (\%torq x dk) arasında değişmiştir. En yüksek zarf alanı değeri Eminbey çeşidinden elde edilmiştir (Çizelge 3). Farklı tane iriliklerinin ekmeklik buğday kalitesine etkilerinin incelendiği bir çalışmada zarf alanı değeri ortalama 141,79 (\%torq x dk) olarak belirlenmiştir (Aydoğan ve ark., 2014). Zarf alanının kuvvetli unlarda yüksek, zayıf unlarda düşük olması beklenir (Şahin ve ark., 2011). Bu alanın geniş olması gluten bağlarının yoğurma esasında kuvvetli bir yapı oluşturduğunu ve analiz sonuna kadar bu yapının muhafaza edildiğini göstermektedir.

Miksograf toplam alan: Çizelge 3'e göre miksograf toplam alan (TTINT) ortalama 313,11 \%torq x dk olarak bulunmuştur. En yüksek toplam alan Eminbey (357,67 \%torq x dk) çeşidinden elde edilmiştir. Martinant ve ark. (1998) 39 adet ekmeklik buğdayda toplam alanı ortalama 245,5 (\%torqxdk) olarak bildirmișler ve bu parametreyi hamur mukavemetiyle ilişkilendirmişlerdir.

Miksograf skala: Miksograf skala (MS) parametresinin değerlendirmesi; analiz sonunda miksogram yorumlanarak 1-8 arasinda puan verilmesi şeklinde olmaktadır. Genellikle hamur mukavemetinin bir göstergesi olarak değerlendirilmektedir (Abuhammad ve ark., 2012). Özellikle 5 puan üzerinde miksograf skala değerine sahip olan genotipler kuvvetli reolojik özellikere sahip olmaktadır. Bu çalışmada miksogramlara (miksograf grafiklerine) verilen puanlar 3,0-7,5 arasında değişmiş ve en yüksek puanı Eminbey, en düşük puanı ise Kızıltan çeşidi almıştır (Çizelge 3). Benzer bir çalışmada ise Abuhammad ve ark. (2012) 3 farklı lokasyonda değerlendirdikleri 16 farklı durum buğdayında miksograf skala değerinin 2,7 ile 7,7 puan arasında değiştiğini belirtmiş, miksograf cihazının az miktarda örnekle kısa sürede reolojik özelliklerin tespitinde uygun bir cihaz olabileceğini bildirmiştir.

Makarnalık buğdayların kuru ve sulu koşullardaki miksograf analiz sonuçları Çizelge 3 'te verilmiş olup, PT değeri hariç tüm miksograf parametrelerin sulu koşullardaki değerleri kuru koşullardaki değerlerden yüksek bulunmuştur. Eminbey çeşidi sulu ve kuru koşullarda PT, TINT, TTINT ve MS değerleri içerisinde en yüksek değere, RPS değerinde ise en düşük değere sahip olmuştur. CT değerinde ise her iki koşulda da Kızıltan çeşidi en düşük değeri elde etmiştir.

\section{Özellikler Arası İlişkiler}

Denemede kalite parametreleri arasındaki korelasyonlar Çizelge 4'te belirtilmiştir. PT ile SDS $(\mathrm{r}=+0,862)$, DDT $(\mathrm{r}=+0,791)$, STB $(\mathrm{r}=+0,862), \mathrm{PV}$ $(\mathrm{r}=+0,588) \quad \mathrm{CT} \quad(\mathrm{r}=+0,862), \quad$ TINT $\quad(\mathrm{r}=+0,947)$, TTINT $(\mathrm{r}=+0,820)$ ve Miksograf skala $(\mathrm{r}=+0,904)$ pozitif, DS12 $(r=-0,848)$ ile ve RPS $(r=-0,825)$ ile negatif önemli $(p<0,01)$ ilişki göstermiştir. SDS analizi protein kalitesini gösterdiğinden PT ile pozitif korelasyon göstermesi beklenen bir durumdur. Benzer şekilde Dexter ve ark. (1980) yaptıkları çalışmada miksograf gelişme süresi ve SDS analizi arasinda pozitif korelasyon $(0,69)$ belirlemişlerdir.

PV ile SDS $(\mathrm{r}=+0,654)$ ve DDT $(\mathrm{r}=+0,425)$, STB $(\mathrm{r}=+0,483)$, TINT $(\mathrm{r}=+0,643)$, TTINT $(\mathrm{r}=+0,897)$ arasında pozitif, DS12 ( $\mathrm{r}=-0,643)$ ile negatif önemli $(\mathrm{p}<0,01)$ iliş̧ki belirlenmiştir. Atlı ve ark. (1992) pik yüksekliği ile sedimantasyon değeri arasında önemli ilişki olduğunu $(0,649)$ belirtmişlerdir.

RPS ile SDS ( $r=-0,726)$, STB ( $r=-0,704)$, CT $(r=-$ $0,833)$, TINT $(\mathrm{r}=-0,893)$, TTINT $(\mathrm{r}=-0,711)$ ve DDT $(\mathrm{r}=-0,548)$ ve Miksograf skala $(\mathrm{r}=-0,845)$ değerleri arasinda $(\mathrm{p}<0,01)$; WAC $(\mathrm{r}=-0,383)$ ve PV $(\mathrm{r}=-$ $0,380)$ değerleri ile de negatif ilişki $(p<0,05)$ belirlenmiştir. DS12 $(\mathrm{r}=+0,676)$ değeri ile arasında ise pozitif önemli ilişki $(\mathrm{p}<0,01)$ bulunmuştur. Bağc1 (1998) yaptığı çalışmada RPS ile protein ile $(\mathrm{r}=-0,31)$ ve SDS değeri arasında $(\mathrm{r}=-0,10)$ negatif önemsiz korelasyon bulunduğunu bildirmiştir. RPS yumuşama derecesi hakkında fikir verdiğinden kuvvetli hamurlarda düşük olması istenen bir değerdir. Dolayısıyla hamurda protein kalitesini gösteren SDS sedimantasyon değeri ile negatif, DS12 değeri ile pozitif ilişki göstermesi literatür sonuçları ile uyumludur. 


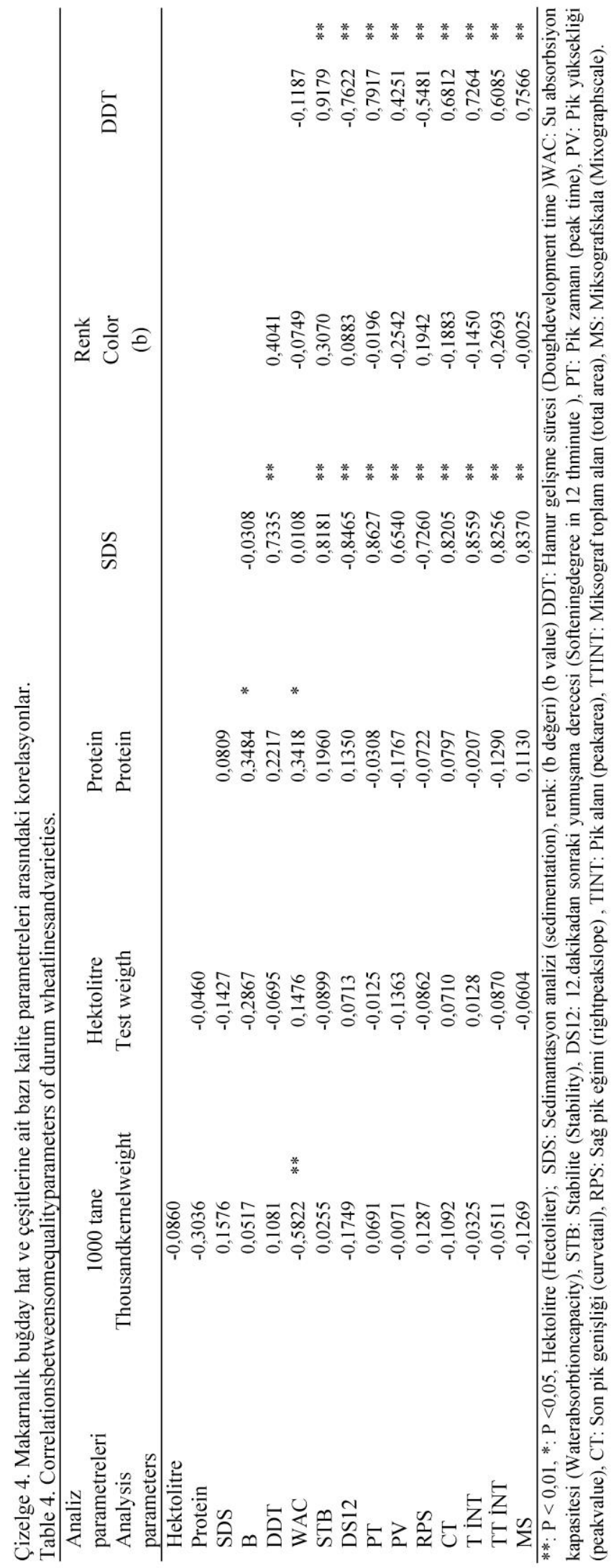


B. DEMIR, M S SAHIN, A GÖCMEN AKÇACIK, S. AYDOĞAN, S. HAMZAOĞLU, C. MECITOĞLU GÜCBILMEZ, S. GÜR, M. TÜRKÖZ: SULU VE KURU KOSSULLARDA YETISTTIRILEN MAKARNALIK BUĞDAY (Triticum durum L.) GENOTIPLERINDE BAZI KALITE ÖZELLIKLERİNIN MIKSOGRAF CIHHAZI İLE DEĞERLENDİİLMESI




CT ile SDS $(\mathrm{r}=+0,820)$, DDT $(\mathrm{r}=+0,681)$, STB $(\mathrm{r}=+0,824)$, TINT $(\mathrm{r}=+0,938)$, TTINT $(\mathrm{r}=+0,806)$ ve Miksograf skala $(r=+0,902)$ değerleri arasında $\mathrm{p}<0,01$ seviyesinde pozitif ilişki belirlenirken, DS12 ( $r=-0,802)$ değeri ile $\mathrm{p}<0,01$ düzeyinde negatif ilişki belirlenmiștir. CT hamur mukavemeti ve gluten kalitesinin göstergesi olduğundan bu çalışmada da yumuşama derecesi ile negatif ilişki göstermiştir. Bir başka çalışmada bu sonuçlara paralel olarak CT ile SDS arasinda $(\mathrm{r}=+0,423)$ pozitif korelasyon olduğu bildirilmiştir (Şahin ve ark. 2011).

TINT ile SDS $(\mathrm{r}=+0,855)$, DDT $(\mathrm{r}=+0,726)$, STB $(\mathrm{r}=+0,853)$, TTINT $(\mathrm{r}=+0,881)$ ve Miksograf skala $(\mathrm{r}=+0,940)$ değerleri arasında pozitif, DS12 ( $\mathrm{r}=-$ $0,840)$ değeri ile de negatif ilişki ( $\mathrm{p}<0,01)$ göstermiştir. TTINT ile SDS $(\mathrm{r}=+0,825)$, DDT $(r=+0,608)$, STB $(r=+0,694)$ ve Miksograf skala $(\mathrm{r}=+0,839)$ ile pozitif $(\mathrm{p}<0,01)$ ve DS12 $(\mathrm{r}=-$ $0,844)$ ile negatif ilişki $(p<0,01)$ göstermiştir.

Miksograf skala ile SDS $(\mathrm{r}=+0,837), \quad$ STB $(\mathrm{r}=+0,879)$, DDT $(\mathrm{r}=+0,756)$ ile $(\mathrm{p}<0,01)$ pozitif, DS12 $(r=-0,787)$ ile $(\mathrm{p}<0,01)$ negatif ilişki göstermiştir. Miksograf skala değeri miksogramın analiz sonunda yorumlanması ile elde edilir. Bant genişliğinin fazla, kurve altında kalan alanının geniş ve kurve sağ pik eğiminin az olduğu grafiklerin puanlaması yüksek olurken bunun tam tersi durumlarda puanlama düşük olmaktadır.

Benzer bir çalışmada Aydoğan ve ark. (2013) ekmeklik buğday unlarında bazı kimyasal analiz parametreleri ile miksograf ve farinograf parametreleri arasında korelatif ilişkileri yorumlamışlardır. PV ile zeleny sedimantasyon $(\mathrm{r}=+0,616)$ arasinda $(\mathrm{p}<0,01)$ pozitif, TINT ile zeleny sedimantasyon arasinda $(\mathrm{r}=+0,859)(\mathrm{p}<0,01)$ düzeyinde pozitif, TTINT ile protein $(\mathrm{r}=+0,290)$ ve PV $(r=+0,387)$ arasında $(\mathrm{p}<0,05)$ pozitif ilişki tespit etmişlerdir. Ayrica WAC ile protein $(\mathrm{r}=+0,403)$ arasinda $(\mathrm{p}<0,01)$ pozitif; DS12 ile protein $(\mathrm{r}=+0,356)$ ve TTINT $(\mathrm{r}=+0,372)$ arasinda $(\mathrm{p}<0,05)$ pozitif ilişki belirlemişlerdir.

$\mathrm{Bu}$ çalışma sonucunda dikkat çeken sonuçlardan biri SDS sedimantasyon değerinin birçok miksograf parametresiyle önemli korelasyonlar göstermesi olmuştur. Nitekim Kovacs ve ark. (1997), Kanada'da 3 y1l yetiştirilen durum buğdaylarının SDS sedimantasyon değeri ile miksograf parametreleri ve makarna pişme kalitesiyle güçlü korelasyonlar olduğunu belirlemesi bu çalışmada elde edilen sonuçlarla uyumludur. Benzer bir çalışmada makarna kalitesini belirlemede SDS sedimantasyon, protein içeriği ve miksograf parametreleri kombinasyonu kullanımının iyi bir tahmin yöntemi olduğunu ifade edilmiştir (Dick ve Quick, 1983).

\section{SONUÇ}

Durum buğdayının kalitesini belirleyen temel unsur; buğdayın makarna üretimine uygunluk derecesidir. Tanenin fiziksel özellikleri ve kimyasal bileşimi makarnalık buğdaydan elde edilen son ürün kalitesi ile doğrudan ilişkilidir. Makarnalık buğdayların kalite özelliklerinin belirlenmesinde protein miktar ve kalitesi, irmik rengi ve verimi, cams1 tane oran1, bin tane ağırlığı ve hektolitre ağırlığ 1 gibi kalite kriterleri ön plandadır. Miksogram değerlerinden MS değeri gluten kuvvetini oldukça net şekilde gösteren önemli bir parametredir. Bu çalışmada MS değeri SDS, DDT, STB, PT, PV, TINT ve TTINT parametreleriyle arasinda pozitif; DS12 ve RPS parametreleriyle de negatif ilişki $(p<0,01)$ belirlenmiştir. Elde edilen sonuçlar miksograf cihazından elde edilen verilerin diğer kalite parametreleri ve özellikle de farinograf cihazı sonuçları ile önemli ilişkiler gösterdiğini doğrular niteliktedir. Makarnalı buğday 1slah programlarında erken generasyonda daha az miktarda örnekle daha kısa sürede analiz yapılarak kalite açısından önemli çıktılar veren miksograf cihazının kullanımının seleksiyonda kolaylık sağlayacağ 1 düşünülmektedir. Ancak, bu konu yapılacak ileri çalışmalarla miksograf cihazının makarnalık buğdayda kullanımına katk1 sağlayacaktır. Ülkemiz, dünyada yüksek kaliteli makarnalık buğday üretimine uygun farklı ekolojik bölgelere sahip ülkelerden birisidir. Makarnalık buğday üretiminde kalitenin artırılması için öncelikle ülkemizin verim ve kalite bakımından iyi sonuç alınabileceği bölgelerin belirlenerek ıslah çalışmalarının bu bölgelerde yoğunlaştırılması ve sadece verimi yüksek buğday üretimine odaklanmak yerine, buğdayın kalite ve hastalıklara dayanıklılık gibi özelliklerinin de dikkate alınarak farklı disiplinlerle bir arada değerlendirilmesi gerekmektedir. 
B. DEMIR, M. SAHIN, A. GÖCMEN AKCACIK, S. AYDOĞAN, S. HAMZAOĞLU, C. MECITOĞLU GÜÇIILMEZ, S. GÜR, M. TÜRKÖZ: SULU VE KURU KOŞULLARDA YETIŞTIRILEN MAKARNALIK BUĞDAY (Triticum durum L.) GENOTIPLERINNDE BAZI KALİTE ÖZELLIKKLERİNIN MIKSOGRAF CIHHAZI İLE DEĞERLENDİILLMESI

\section{LITERATÜR LISTESI}

Abu Hammad, W. A., E. M. Elias, F. A., Manthey, M. S. Alamri, and M. Mergoum. 2012. A comparison of methods for assessing dough and gluten strength of durum wheat and their relationship to pasta cooking quality. International Journal of Food Science \& Technology 47 (12): 2561-2573.

Altan, A. 1996. Yayınlanmamış Ders Notları. Çukurova Üniversitesi. Adana.

Anonymous. 2000. Approved Methods of American Association of Cereal Chemists.10th ed. Methods (AACC). Minnesota. USA.

Anonymous. 2014. JMP11, JSL Syntax Reference. SAS Institute. ISBN: 978-1-62959-560-3.

Atlı, A. 1985. İç Anadolu'da yetiștirilen bazı ekmeklik buğday çeşitlerin kalite özellikleri üzerine çevre ve çeşidin etkisi. Doktora tezi. A. Ü. Zir. Fak. Fen Bil Enst. Ankara.

Atl1, A. 1987. Kışlık tahıl üretim bölgelerimizde yetiştirilen bazı ekmeklik ve makarnalık buğday çeșitlerinin kaliteleri ile kalite karakterlerinin stabilitesi üzerine araştırmalar. Türkiye Tahıl Sempozyumu. 6-9 Ekim Bursa. s. 443- 454.

Atlı, A., H. Köksel ve Z. Demir. 1992. Ekmeklik buğdayların kalitelerinin belirlenmesinde miksograf kullanım üzerine araştırmalar. Gıda 17 (6): 387-394.

Aydemir, T., Ö. Dönmez, K. Yılmaz ve N. Sezer. 2003. Tescilli makarnalık buğday çeşitlerinin verim ve kalite yönünden değerlendirilmesi. Türkiye 5. Tarla Bitkileri Kongresi. 13-17 Ekim 2003. Diyarbakır, s. 498-506.

Aydoğan, S., A. Göçmen Akçacık, M. Şahin, Y. Kaya, S. Taner, B. Demir ve H. Önmez. 2010. Ekmeklik buğday çeşitlerinin dane verimi bazı kimyasal ve reolojik özellikler üzerine bir araştırma. Bitkisel Araştırma Dergisi 1: 1-7.

Aydoğan, S., A. Göçmen Akçacık, M. Şahin, B. Demir, H. Önmez ve S. Çeri. 2012a. Bazı makarnalık buğday çeşitlerinin kalite özelliklerinin belirlenmesi. Tarla Bitkileri Merkez Araştırma Enstitüsü Dergisi. 21 (1): 1-7.

Aydoğan, S., A. Göçmen Akçacık, M. Şahin, Y. Kaya, H. Koç, M. N. Görgülü ve M. Ekici. 2012b. Ekmeklik buğday unlarında alveograf, farinograf ve miksografta ölçülen reolojik özellikler arasındaki ilişkinin belirlenmesi. Süleyman Demirel Üniversitesi Zir. Fak. Dergisi 7 (1): 74-82.

Aydoğan, S., A. Göçmen Akçacık, M. Şahin, H. Önmez, B. Demir ve E. Yakışır. 2013. Ekmeklik buğday çeşitlerinde fizikokimyasal ve reolojik özelliklerin belirlenmesi. Tarla Bitkileri Merkez Araştırma Enstitüsü Dergisi 22 (2): 74-85.
Aydoğan, S., M. Şahin, A. Göçmen Akçacık ve E. Yakışır. 2014. Farklı tane iriliğinin ekmeklik buğday kalitesine etkisi. Selçuk Tarım Bilimleri Dergisi 1 (1): 27-33.

Babay, E., M. Hanana, R. Mzid, H. Slim-Amara, J. M. Carrillo, and M. Rodríguez-Quijano. 2015. Influence of allelic prolamin variation and localities on durum wheat quality. Journal of Cereal Sci. 63: 27-34.

Bağcı, S. A. 1998. Multivariate analysis of computerized mixograph data for end-use quality improvement in winter wheat. M.Sc. thesis. South Dakota State University. SD. USA.

Bağc1, S. A. ve M. Şahin, 1999. Buğday kalite 1slahında bilgisayarlı mixograf aletinin kalite ölçümünde kullanılması. Orta Anadolu'da Hububat Tarımının Sorunları ve Çözüm Yolları. 8-11 Haziran. s. 519-523. Konya.

Bakhshi, A. K., and G. S. Bains. 1987. Study of the physicochemical, rheological, baking and noodle quality of improved durum and bread wheat cultivars. J. Food Sci. Technol. 24: 217-221.

Blue, E., S. Mason, and D. Sander. 1990. Influence of planting date, seeding rate, and phosphorus rate on wheat yield. Agronomy Journal 82 (4): 762-768.

Borrelli, G. M., A. Troccoli, C. Fares, D. Trono, A. M. De Leonardis, L. Padalino, D. Pastore, L Del Giudice, and N. Di Fonzo. 2000. Lipoxygenase in durum wheat: what is the role in pasta colour? CIHEAM- Options Mediterraneennes, pp. 497-499.

Boyacıŏlu, M. H., and B. L. D'appolonia. 1994. Characterization and utilization of durum wheat for breadmaking. I. Comparison of chemical, rheological, and baking properties between bread wheat flours and durum wheat flours. Cereal Chem. 71 (1): 21-27.

Bushuk, W. 1998. Wheat breeding for end-product use. Euphytica 100 (1-3): 137-145. https:// doi.org/10.1023/A:1018368316547.

Coşkun, Y., A. İlkhan, M. Köten ve A. Coşkun. 2010. Güneydoğu Anadolu Bölgesi'nde yetiştirilen farklı makarnalık buğday çeşitlerinin kalite yönünden değerlendirilmesinde $b$ ve $b^{*}$ renk değerlerinin kullanılabilirliğinin incelenmesi. Harran Üniversitesi Zir. Fak. Dergisi 14 (3): 25-29.

Dalçam, E. 1993. Makarnalık buğdaylarda aranan kalite kriterleri. Makarnalık Buğday ve Mamulleri Sempozyumu, s: 307-309. Ankara.

Deng, Z. Y., J. C. Tian, H. W. Zhang, Y. X. Zhang, and Y. L. Liu. 2005. Application of farinograph quality number (FQN) in evaluating dough and baking qualities of winter wheat. Acta Botanica Boreali-Occidentalia Sinica 25: 673-680. (in Chinese). 
Dexter, J. E., R. R. Matsuo, F. G. Kosmolak, D. Leisle, and B. A. Marchylo. 1980. The suitabilily of the SDSsedimentation test for assessing gluten strength in durum wheat. Can. J. Plant Sci. 60: 25-29.

Dick, J. W., and J. S. Quick. 1983. A modified screening test for rapid estimation of gluten strength in early generation durum wheat breeding lines. Cereal Chem. 60: 315-318.

Dong, H., R. G. Sears, Cox T. S., Hoseney R. C.,. Lookhart G. L, and M. D. Shogren. 1992. Relationship between protein composition and mixograph and loaf characteristics in wheat. Cereal Chem. 69: 132-136.

D'ovidio, R., and S. Masci. 2004. The low-molecularweight glutenin subunits of wheat gluten. Journal of Cereal Sci. 39: 321-339.

Edwards, N. M., and J. E. Dexter. 2009. Factors associated with the bread- making potential of durum wheat, Chapter 3, pp.47-62. In: Taylor John R. N., and R. L. Cracknell (Eds.). The ICC Book of Ethnic CrealBased Foods Baverages Across the Continents, The University of Pretoria Lynnwood Rood Pretoria, South Africa.

Edwards, N. M., J. E. Dexter, M. G. Scanlon, and S. Cenkowski. 1999. Relationship of creep-recovery and dynamic oscillatory measurements to durum wheat physical dough properties. Cereal Chem. 76 (5): 638645.

Elgün, A. ve Z. Ertugay. 1995. Tahıl İşleme Teknolojisi. Atatürk Üniversitesi Ziraat Fakültesi Yayın No: 297 (2.Bask1), Erzurum, 481s.

Ercan, R., R. Seçkin ve S. Velioğlu. 1988. Ülkemizde yetiştirilen bazı buğday çeşitlerinin ekmeklik kalitesi. Gida Dergisi 13 (2): 107-114.

Feillet, P., and J. E. Dexter. 1996. Quality requirements of durum wheat for semolina milling and pasta production. 95-131. In: J. E. Kruger, R.R. Matsuo and J.W. Dick (Ed.) Pasta and Noodle Technology. eds. American Association of Cereal Chemists. St. Paul. MN.

Kaplan Evlice, A. ve H. Özkaya. 2011. Makarnalık buğdayda farklı cihazlarla saptanan renk değerinin kalite yönünden değerlendirilmesi. Tarla Bitkileri Merkez Araştırma Enstitüsü Dergisi 20 (2): 33-40.

Karababa, E. ve R. Ercan. 1995.Makarnalık buğdayların ekmeklik potansiyeli ve kalitesi. G1da. 20 (3): 153159.

Kendal, E., S. Tekdal, H. Aktaş, ve M. Karaman. 2012. Bazı makarnalık buğday çeşitlerinin Diyarbakır ve Adıyaman sulu koşullarında verim ve kalite parametreleri yönünden karşılaştırılması. Uludağ Üniversitesi Zir. Fak. Dergisi 26 (2): 1-14.
Khatkar, B. S., A. E. Bell, and J. D. Schofield. 1996. A comparative study of the interrelationship between mixograph parameters and breadmaking qualities of wheat flours and glutens. Journal of the Science of Food and Agriculture 72: 71-85.

Kılıç, H., S. Tekdal, E. Kendal, ve H. Aktaş. 2012. Augmented deneme desenine dayalı ileri kademe makarnalık buğday (Triticum turgidum Ssp.) hatlarının biplot analiz yöntemi ile değerlendirilmesi. Kahramanmaraş Sütçü İmam Üniversitesi Doğa Bilimleri Dergisi 15 (4): 131145 .

Kovacs, M. I. P., N. K. Howes, D. Leisle, and J. Zawıstowsk1. 1995. Effect of two different low molecular weight glutenin subunits on durum wheat pasta quality parameters. Cereal Chem. 72 (1): 85-87.

Kovacs, M. I. P., L. M. Poste, G. Butler, S. M. Woods, D. Leisle, J. S. Noll, and G. Dahlke. 1997. Durum wheat quality: Comparison of chemical and rheological screening tests with sensory analysis. Journal of Cereal Sci. 25: 65-75.

Liu, C. Y., K. W. Shepherd and A. J. Rathjen. 1996. Improvement of durum wheat pasta making and breadmaking qualities. Cereal Chem. 73: 155-166.

Martinant, J. P., Y. Nicolas, A. Bouguennec, Y. Popineau, L. Saulnier, and G. Branlard. 1998. Relationships between mixograph parameters and indices of wheat grain quality. Journal of Cereal Sci. 27: 179-189

Nachit, M. M., M. Baum, A. Impiglia, and H. Ketata. 1995. Studies on some grain quality traits in durum wheat grown in Mediterranean environments in durum wheat improvement in the Mediterranaen region: Serie A. Seminaries Mediterraneens n.22. CIHEAM- Options Mediterranean Zaragoza, Spain. pp. 181-187.

Özkaya, H. ve B. Kahveci. 1990. Tahıl ve Ürünleri Analiz Yöntemleri. Gıda Teknolojisi Derneği Yayınları. Ankara.

Patil, R. M., M. D. Oak, S. A. Tamhankar, and V. S. Rao. 2009. Molecular mapping of QTLs for gluten strength as measured by sedimentation volume and mixograph in durum wheat (Triticum turgidum L. ssp durum), Journal of Cereal Sci. 49: 378-386.

Pitz, W. J. 1997. Mixograph application for the evaluation of wheat used for pasta. pp. 65. In: Walker C. E., J. L. Hazelton, and M. D. Shogren (Ed.). The Mixograph Handbook. 1st ed. National Manufacturing Division, Lincoln, NE, USA.

Pudden, R. M. 1997. Use of the Mixograph for Better Management of Wheat Selection Decisions. pp.71. In: Walker, C. E., J. L. Hazelton, and M. D. Shogren. (Eds.) The Mixograph Handbook, 1st ed. National Manufacturing Division, Lincoln, NE, USA. 
B. DEMIR, M. SAHİN, A. GÖCMEN AKÇACIK, S. AYDOĞAN, S. HAMZAOĞLU, C. MECITOĞLU GÜÇIILMEZ, S. GÜR, M. TÜRKÖZ: SULU VE KURU KOSSULARDA YETISTTIRILEN MAKARNALIK BUĞDAY (Triticum durum L.) GENOTIPLERINDE BAZI KALİTE ÖZELLIKLERININ MIKSOGRAF CIHAZI İLE DEĞERLENDIRİLMESİ

Sakin, M. A., A. Sayaslan, O. Düzdemir, and F. Yüksel. 2011. Quality characteristics of registered cultivators and advanced lines of durum wheats grown in different ecological regions of Turkey. Canadian Journal Plant Sci. 2 (91): 261-271.

Steel, R. G. D., and J. H. Torrie. 1980. Principles and procedures of statistics. A biometrical approach, 2nd Edition, McGraw-Hill Book Company, New York.

Sun, J. Z., W. L. Yang, D. C. Liu, J. T. Zhao, G. B. Luo, X L1, Y. Liu, J.K. Guo, and A.M. Zhang. 2015. Improvement on mixograph test through water addition and parameter conversions. Journal of Integrative Agriculture 14 (9): 1715-1722.

Şahin, M., A. Göçmen Akçacık, S. Aydoğan, S. Taner ve R. Ayrancı. 2011. Ekmeklik buğdayda bazı kalite özellikleri ile miksograf parametreleri arasındaki ilişkilerin incelenmesi. Tarla Bitkileri Merkez Araştırma Enstitüsü Dergisi 20 (1): 6-11

Şahin, M., A. Göçmen Akçacık, S. Aydoğan ve E. Yakışır. 2016. Orta Anadolu sulu koşullarında bazı kışlık ekmeklik buğday genotiplerinin verim ve kalite performanslarının belirlenmesi. Tarla Bitkileri Merkez Araştırma Enstitüsü Dergisi (Özel sayı-1) 25: 19-23.

Troccoli, A., G. M. Borreli, P. De Vita, C. Fares, and N. Di Fonzo. 2000. Durum wheat quality: A multi disciplinary concept. Journal of Cereal Sci. 32: 99113
Turan, İ. 2008. Kahramanmaraş koşullarında bazı buğday, arpa ve tritikale çeșitlerinin verim ve verim özelliklerinin belirlenmesi. Yüksek Lisans Tezi. Sütçü İmam Üniversitesi, Fen Bilimleri Enstitüsü. Kahramanmaraş.

Walker, C. E., J. L. Hazelton, and M. D. Shogren. 1997. The Mixograph Handbook, National Manifacturing Division, TMCO, Lincoln, NE 68508-2935, USA

Wang, J., C. M. Rosell, and B. C. Benedito. 2002. Effect of the addition of different fibres on wheat dough performance and bread quality. Food Chem. 79: 221226.

Williams, P., J. F. El-Haramein, H. Nakkoul, and S. Rihawi. 1988. Crop quality evaluation methods and guidelines. Sodium Dodecyl Sulphate (SDS) Sedimentation. pp.13-16 International Center For Agricultural Research in The Dry Areas (ICARDA), Syria.

Yurtsever, N. 1984. Deneysel İstatistik Metotlar, Toprak ve Gübre Araştırma Enst. Müd. Yayınları No. 121: 56

Yürür, N. 1994. Serin İklim Tahılları, Tahıllar-I. Uludağ Üniversitesi Yayınları No: 7-035-0295, Uludağ, 69s. 